McElroy, L. W., Clandinin, D. R., Lobay, W. \& Pethybridge, S. I. (1949). F. Nutrit. 37, 329.

Morrison, F. B. (1947). Feeds and Feeding, 2oth ed. New York: The Morrison Publishing Co.

Osborne, T. B. (1924). The Vegetable Proteins, 2nd ed., p. ro. New York: Longmans, Green and Co.

Osborne, T. B. \& Voorhees, C. G. (1893). Amer. chem. Y. 15, 392.

Rees, .M. W. (1946). Biochem. Y. 40, 632.

Richardson, C. (1886). Bull. U.S. Bur. Chem. no. 9.

Sauberlich, H. F. \& Baumann, C. A. (1949). F. biol. Chem. 177, 545.

Snell, E. E. (1945). Adv. Protein Chem. 2, 99.

Stokes, J. L., Gunness, M., Dwyer, I. M. \& Caswell, M. C. (1945). F. biol. Chem. 160, 35.

Teller, G. I. (1896). Bull. Ark. agric. Exp. Sta. no. 42, Parts 1 and 2.

Teller, G. L. (1932). Cereal Chem. 9, 261.

Tristram, G. R. (1939). Biochem. F. 33, 1271.

Van Slyke, D. D., Hiller, A., Dillon, R. T. \& MacFadyen, D. (1938). Proc. Soc. exp. Biol., N.Y., 38,548 .

\title{
Changes Occurring in the Proteins as a Result of Processing Groundnuts under Selected Industrial Conditions.
}

\section{Physical and Chemical Changes}

\author{
BY J. W. LORD AND J. A. WAKELAM \\ Research Department, $\mathcal{F}$. Bibby and Sons Ltd., Liverpool
}

(Received 6 March I950)

Considerable quantities of groundnuts are being processed in oil-mills in this country and it is reasonable to suppose that the amount will increase in the future. The high oil content $(44-50 \%)$ of the decorticated seed makes groundnuts more difficult to process than most high-protein seeds. In particular, the oil is not so easily extracted as from soya and cottonseed (oil content about $20 \%$ ). Much work has been done on cottonseed and soya beans in the United States, where they are major crops. Little work has so far been published on groundnuts in America, and attention in this country has largely concentrated on maximal oil extraction. The very serious shortage of animal protein available for non-human consumption enhances, however, the importance of vegetable sources of protein and makes it essential that wastage or damage of such protein shall be avoided wherever possible.

The present investigation was carried out using industrial plant under selected conditions considered commercially feasible, and it is essentially a study of the effects of temperature and humidity on the protein. As a background to this work, a brief outline of typical oil-mill practice may be relevant.

The groundnut seeds are usually received in a decorticated state, and it was on material of this type that the present work was done. The raw material is first subjected in steam-heated pots to a slight cooking process lasting $15^{-20} \mathrm{~min}$. at a temperature of 90-100 using dry heat. The object of this is to give the nuts mechanical strength for the subsequent treatment which consists of screw-pressing in 'expeller' machines. 'These machines consist essentially of a conical steel shaft set with its axis horizontal and bearing a raised steel thread which turns in a conical steel housing. The material, introduced at the base of the cone, is 'wormed' toward the apex and crushed between 
the steel faces. The duration of this stage is about $2 \mathrm{~min}$. and the temperature is usually close to $100^{\circ}$. After a variable number of 'expelling' operations, usually two or three, the cake, as it is now called, having an oil content of $20-25 \%$, is passed on for extraction. The details of this next step vary considerably, but it consists of the removal of the residual oil (less than $25 \%$ ) from the 'expeller cake' by means of a solvent such as trichlorethylene or naphtha. The mixture of solvent and oil then drains away and the solvent remaining in the meal is removed by methods which will be detailed later.

\section{METHODS}

Meals. Four experimental meals were used. They consisted of a reference meal prepared by ether extraction of nuts crushed in the laboratory and of three products obtained under manufacturing conditions, the details being as follows: type A, laboratory sample (as above); type B, product of screw-pressing (expelling) in three stages; type $\mathrm{C}$, product of screw-pressing in two stages followed by solvent extraction, the solvent being removed from 2-ton batches by steaming for $30-40 \mathrm{~min}$. at the rate of $2000 \mathrm{lb}$. steam/hr.; type $\mathrm{D}$, as type $\mathrm{C}$, but solvent removed continuously by heating with minimal quantities of steam (much less than $100 \mathrm{lb}$./hr.).

Preliminary analysis. Estimations of oil, moisture and Kjeldahl nitrogen were made on the experimental material ('lable $\mathrm{I}$ ) and meals $\mathrm{A}$ and $\mathrm{B}$ were then reduced to a substantially oil-free state $(<2 \cdot 0 \%)$. The catalysts used in the Kjeldahl estimations were copper and potassium sulphates and the Kjeldahl-Gunning-Arnold method was employed (Association of Official Agricultural Chemists, 1930).

Physical examination. Colour observations were made visually.

Solubility studies. These were made by a number of methods. Preliminary tests using the salt-peptization method of Fontaine \& Burnett (1944), Fontaine, Samuels \& Irving (1944) and a simplified technique based on the method of Almquist, Stokstad \& Halbrook (1935) showed considerable variations between the experimental meals. More detailed work was therefore carried out using the nitrogen-distribution method of Lund \& Sandstrom (I943). This consists essentially of extracting the meal successively with water, $5 \% \mathrm{KCl}$ solution and $0.2 \% \mathrm{KOH}$ solution. The fractions so obtained were referred to by the original authors as 'albumin', 'globulin', 'glutelin' and 'residual nitrogen', and this nomenclature has been retained in the present work to avoid additional confusion. Experience has shown that on a given sample of meal it is possible to reproduce results for the several fractions to well within 2 percentage units. The so-called 'prolamine' fraction (percentage solubility in $70 \%$ alcohol after removal of 'albumin' and 'globulin') was omitted from the separations because preliminary experiments showed that it was exceedingly small.

Sulphur content. The peroxide-alkali fusion method of Bailey (1937) was selected, but as the whole meal, rather than a protein fraction, was tested it was necessary to continue the fusion for a longer period (several hours) and to use larger quantities of starting material $(1 \cdot 5 \mathrm{~g}$.). The peroxide and carbonate were mixed in the requisite proportions beforehand as the added meal did not then catch fire. The reason for using the whole meal was that no method could be found for obtaining all the protein free from carbohydrate. Much of the protein is difficult to dissolve even in alkaline media. 
It is never easy to secure truly representative samples of the kinds of large-scale industrial products with which this work is concerned. It was therefore necessary to carry out a large number of analyses, and those quoted (Table I) are typical of the rest. As will be shown, the range of results for separate samples of the same type of meal is due not only to sampling difficulties but also to uncontrolled variations in the raw material from which the industrial products were derived.

Table I. Preliminary analyses of representative samples of four types of groundnut meal prepared by different industrial processes

$\begin{array}{cc}\begin{array}{c}\text { Type of } \\ \text { meal* }\end{array} & \begin{array}{c}\text { No. of } \\ \text { samples }\end{array} \\ \text { A } & 6 \\ \text { B } & 5 \\ \text { C } & 6 \\ \text { D } & 4\end{array}$

$\begin{array}{cc}\text { Oil } & \begin{array}{c}\text { Moisture } \\ (\%)\end{array} \\ (\%) & 10 \cdot 5-11 \cdot 3 \\ 0.5-1 \cdot 0 & 8-9 \\ 8-9 \cdot 5 & 7-8 \\ 1-1 \cdot 5 & 6-8 \\ 0.5-1 \cdot 2 & \end{array}$

Nitrogen by
Kjeldahl
$(\%)$
$7 \cdot 9-8 \cdot 1$
$7 \cdot 1-7 \cdot 3$
$8 \cdot 0-8 \cdot 3$
$8 \cdot 2-8 \cdot 3$

- See p. I 55 .

The appearance of the meals was characteristic of the type. Meal A was almost pure white apart from occasional particles of the skin (testa) of the nuts, whereas meal B was a medium brown hue much of which, however, was due to the high oil content. Meal D, which, as will be seen, bore some resemblance to meal B in other properties, was a very light brown colour similar to that of meal B when the rest of the oil had been removed. Meal C, however, despite the low oil content, was very dark brown and in contrast with $\mathrm{D}$ appeared homogeneous, no particles of skin being discernible.

Table 2. Results of salt-peptization tests with four types of groundnut meal prepared by different industrial processes

$\begin{array}{ccc}\begin{array}{c}\text { Type of } \\ \text { meal* }\end{array} & \begin{array}{c}\text { No. of } \\ \text { samples }\end{array} & \begin{array}{c}\text { Percentage } \\ \text { nitrogen } \\ \text { peptizable } \\ \text { by } 5 \% \mathrm{NaCl}\end{array} \\ \text { A } & 5 & 82-88 \\ \text { B } & 4 & 71-74 \\ \text { C } & 5 & 26-31 \\ \text { D } & 4 & 70-73 \\ & * \text { See p. 155. } & \end{array}$

The salt-peptization results (Table 2) distinguish sharply between the types of meals, the results falling within the ranges shown.

In evaluating the various fractions contributing to the 'protein-quality index' of Almquist et al. (1935), marked differences between the meals were found, but the results were difficult to interpret, and the index (which was not intended by the original workers to apply to meals of vegetable origin) was of doubtful value here. Attention was next turned to the protein distribution system of Lund \& Sandstrom (1943), the 
results of which applied to soya-bean meal have been interpreted in terms of nutritional value by Evans \& St John (1945). The protein-distribution method revealed rather striking differences between the four types of meal, and the results shown in Table 3 are typical of a large number of estimations on each type.

Table 3. Percentage distribution of protein in four types of groundnut meal prepared by different industrial processes

\begin{tabular}{|c|c|c|c|c|c|}
\hline $\begin{array}{l}\text { Type of } \\
\text { meal* }\end{array}$ & $\begin{array}{c}\text { No. of } \\
\text { samples }\end{array}$ & 'Albumin't & 'Globulin'† & 'Glutelin't & $\begin{array}{l}\text { 'Residual } \\
\text { nitrogen' } \dagger\end{array}$ \\
\hline $\begin{array}{l}\text { A } \\
\text { B }\end{array}$ & $\begin{array}{l}3 \\
8\end{array}$ & $\begin{array}{l}74.3 \\
56.8\end{array}$ & $9 \cdot 2$ & $\begin{array}{r}7.9 \\
18.4\end{array}$ & $\begin{array}{l}8 \cdot 6 \\
7 \cdot x\end{array}$ \\
\hline $\mathrm{C}$ & 7 & $32 \cdot 7$ & 9.5 & $34 \cdot 1$ & 23.7 \\
\hline D & 3 & $68 \cdot \mathrm{I}$ & 9.8 & 13.0 & $9 \cdot I$ \\
\hline
\end{tabular}

In an effort to identify the factor in the processing which made meal $\mathrm{C}$ so profoundly different from the others, four samples obtained at different stages in the sequence of operations were analysed. It is evident from the results (Table 4) that the cause of the loss of solubility is to be sought in the steaming stage of the process.

Table 4. Changes in percentage distribution of protein during solventextraction of groundnut meal (type $C$ )*

\begin{tabular}{|c|c|c|c|c|}
\hline Stage & 'Albumin'† & 'Globulin' $\dagger$ & 'Glutelin'† & $\begin{array}{l}\text { 'Residual } \\
\text { nitrogen ' }+\end{array}$ \\
\hline $\begin{array}{l}\text { Before extraction } \\
\text { After extraction } \\
\text { After steaming } \\
\text { After drying }\end{array}$ & $\begin{array}{l}62 \cdot 1 \\
56 \cdot 3 \\
26 \cdot 4 \\
25 \cdot 8\end{array}$ & $\begin{array}{r}12 \cdot 5 \\
13.8 \\
9 \cdot 3 \\
9 \cdot 2\end{array}$ & $\begin{array}{l}17 \cdot 3 \\
21 \cdot 2 \\
41 \cdot 0 \\
39 \cdot 2\end{array}$ & $\begin{array}{r}8 \cdot 1 \\
8 \cdot 7 \\
23 \cdot 3 \\
25 \cdot 8\end{array}$ \\
\hline
\end{tabular}

In the chemical studies, the sulphur content has been expressed as percentage of sulphur in protein, taking the nitrogen content of groundnut protein as $18 \cdot 25$ (proteinconversion factor 5.46 , Jones, 1931 ). It became clear from preliminary estimations that there were variations in the sulphur content of different lots of meal of the same type. An investigation of the starting materials revealed that these, too, differed considerably among themselves. A criterion widely accepted as an index of the quality of oilseeds, is the percentage of free fatty acid (F.F.A.) in the extracted oil. Further, it is generally conceded that whole seeds with unbroken testas are in better condition and have lower F.F.A. than broken seeds from which the testas have been partly or wholly removed during storage. In Table 5, therefore, the F.F.A. is quoted to indicate the quality of the seeds, and it will be seen that for meals of type A the sulphur content of the meal and the F.F.A. of the seeds run parallel.

These results explained an early observation that when meal had been heavily steamed hydrogen sulphide was frequently noticed in the mixture of steam and solvent leaving the plant. In order to correlate these chemical results with the solubility 
Table 5. Sulphur content of proteins in groundnut meals of different quality

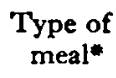

A

B

$\mathrm{C}$

D
Quality of starting material

(i) Average (F.F.A. +6.5 )

(ii) Good (F.F.A.† 3)

(iii) Poor (F.Y.A.† 18)

(iv) Hand picked, good (F.F.A.† 0.8 )

(v) Hand picked, poor (F.F.A. $\nmid \mathbf{2 2} \cdot 5$ )

(i) Good

(ii) Poor

(i) Good

(ii) Poor

Average

\section{Sulphur}

$(\%)$

$1 \cdot 20$

$1 \cdot 32$

1.09

I. 37

$1 \cdot 08$

0.95

0.94

0.77

0.77

0.93

- See p. 155 .

$\uparrow$ Free fatty acid percentage.

measurements, protein-distribution experiments were carried out by the same methods as above, save that duplicate fractions were estimated for total sulphur as well as for total nitrogen. In Table 6 the results are expressed as the percentages of the total

'Table 6. Distribution of sulphur and protein in protein fractions of four types of groundnut meal prepared by different industrial processes expressed as percentages of the total in the meals

Total

Type sulphur

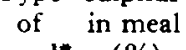

\begin{tabular}{cccc}
\multicolumn{2}{c}{ Albumins' $t$} & \multicolumn{2}{c}{ 'Globulins' $t$} \\
Protein & Sulphur & Protein & Sulphur \\
75.0 & 50.2 & 9.8 & 21.5 \\
71.4 & 45.5 & 8.9 & 17.8 \\
37.4 & 26.0 & 5.9 & 12.3 \\
72.3 & 46.5 & 8.6 & 15.3
\end{tabular}

\begin{tabular}{|c|c|}
\hline \multicolumn{2}{|c|}{ 'Glutelins '† } \\
\hline Protein & Sulphur \\
\hline II $\cdot 8$ & 13.9 \\
\hline $14 \cdot 2$ & $18 \cdot 2$ \\
\hline $34 \cdot 6$ & $34^{\circ} 9$ \\
\hline $15^{\circ} 0$ & 20.5 \\
\hline
\end{tabular}

$\overbrace{\text { Protein }}^{\text {Residual nitrogen't }} \begin{array}{cc}\text { Sulphur } \\ 3.3 & 14.5 \pm \\ 5.7 & 18.5 \ddagger \\ 22.1 & 26.7 \\ 4.1 & 18.7 \pm\end{array}$

- See p. r55.

† Cf. Lund \& Sandstrom (1943).

I The samples for sulphur analysis were very small and these results are therefore not very accurate.

protein and total sulphur contents of the meals found in each of the arbitrary fractions. With sulphur, the figures of Table 5 must be borne in mind when comparing several meals, e.g. the figures for meal A relate to material having $\mathrm{I} \cdot 2 \%$ total sulphur, whereas those for meal $\mathrm{C}$ relate to material having only 0.75 .

In confirming the factor responsible for the damage to the meal (cf. Table 4) by sulphur estimations, a type of plant was used for solvent-removal in which it was possible to control both the amount of steam and the time during which the meal was in contact with the steam. The starting material in this experiment was a batch of good quality nuts which had been 'expelled' less severely than usual so as to damage the protein as little as possible. Before steaming the meal, the excess solvent was drained off and the meal, in thin layers, was submitted to dry heat at about $100^{\circ}$ for some $45 \mathrm{~min}$. Measurements of salt peptization and of total sulphur were then made (Table 7). 
Table 7. Extent of exposure to steam and changes in the proteins of a batch of good quality groundnuts during removal of solvent in the preparation of meal

Amount of steam
Negligible $(<50 \mathrm{lb} . / \mathrm{hr}$.)
Negligible $(<50 \mathrm{lb} . / \mathrm{hr}$.)
$200 \mathrm{lb} . / \mathrm{hr}$.
$200 \mathrm{lb} . / \mathrm{hr}$.
$350 \mathrm{lb} / \mathrm{hr}$.
Meal of type C

Time in contact
Negligible
$60 \mathrm{~min}$.
Negligible
$30 \mathrm{~min}$.
$60 \mathrm{~min}$.
-

DISCUSSION

$\begin{array}{cc}\begin{array}{c}\text { Nitrogen } \\ \text { peptizable } \\ \text { by } 5 \% \mathrm{NaCl}\end{array} & \begin{array}{c}\text { Sulphur } \\ \text { in protein }\end{array} \\ (\%) & (\%) \\ 72.1 & 1.00 \\ 63.9 & 0.96 \\ 72.1 & 0.98 \\ 49.9 & 0.82 \\ 39.7 & 0.77 \\ 31.7 & 0.75\end{array}$

The salt-peptization and protein-distribution results (Tables 2 and 3 ) show clearly that the meals had undergone some change considerably affecting the solubility of their proteins. As other workers, e.g. Almquist et al. (1935), had associated loss of solubility with decreased biological value, feeding tests were undertaken (Cama \& Morton, 1950). The chemical work followed logically and aimed at discovering whether a change more severe than loss of solubility had taken place. As can be seen from the results, this was in fact the case, and the general pattern of the chemical changes consequent upon processing was similar to that of the physical changes. It is evident that the presence of steam is the really damaging factor and, as is shown by Cama $\&$ Morton (1950), the biological value (at least for rats) is adversely affected.

The loss of sulphur, however, requires some further comment in view of the results (Table 5) obtained with different samples of unprocessed nuts. It would seem that there is a very labile fraction which undergoes decomposition during unsatisfactory or prolonged storage. The type of storage that causes damage of this kind is such as to cause purely physical damage coupled with somewhat elevated temperature, the conditions, in fact, of bulk transport and storage. It is also evident that there may be a correlation between loss of sulphur and changes occurring in the oil component of the nuts. This is not to suggest that the two changes are directly connected, but it seems likely that lipolytic and proteolytic enzymes may be liberated at the same time by the rupture of cell walls and that their action, together with other degenerative changes, may proceed simultaneously. It is significant that, after the relatively mild process of 'expelling', the sulphur content of material from the different grades of nuts is substantially the same.

Work is being undertaken to characterize further the sulphur losses and also to investigate whether other degenerative changes occur, but the work so far reported offers conclusive evidence of the gross damage wrought by large quantities of steam.

That some heating of the meal is desirable will be seen from the findings of Cama \& Morton (1950) that 'expeller' meal (type B) is superior to unprocessed nuts in digestibility coefficient and biological value. 'This result suggests at once an analogy with soya-bean meal where a similar improvement has been accounted for, at least in part, by the destruction of a trypsin inhibitor. This inhibitor has been isolated and characterized and shown to be heat labile (Borchers, Ackerson, Sandstedt \& Kimmett, 
1947). Borchers, Ackerson \& Kimmett (1947) have also reported the presence of a trypsin inhibitor in groundnuts, but they do not appear to have pursued the matter. We have, in this laboratory, concentrated such an inhibitor from crushed groundnuts and have shown that its activity is diminished by heat. Work is still proceeding on the subject and it is hoped to report upon it at a later date.

It would seem then that, though some heating of groundnut meal is necessary for the destruction of a trypsin inhibitor, the use of large quantities of steam for removal of residual solvent from the meal is harmful to the proteins, not merely reducing their solubility, but actually destroying some sulphur-containing fragments. Since it is already well known that the protein of groundnuts is deficient in sulphur-containing amino-acids (cf. Grau, 1946) it is important to avoid aggravation of this deficiency. It is evident from the results shown in 'lable 7 that dry heat is much less damaging than steam, and hence the use of steam should be reduced to the barest minimum required for the efficient removal of residual solvent from the meal.

\section{SUMMARY}

I. 'The solubility of the proteins of groundnut meals was considerably diminished by the use of steam during removal of oil solvents.

2. The loss of solubility was accompanied by chemical breakdown involving destruction of some sulphur-containing fragments.

3. These effects were largely avoided by using dry heat and minimal quantities of steam.

We wish to thank the Directors of Messrs J. Bibby and Sons Ltd. for permission to publish this paper.

\section{RFFERENCES}

Almquist, H. J., Stokstad, E. L. R. \& Halbrook, E. R. (1935). F. Nutrit. ro, 193.

Association of Official Agricultural Chemists (1 930). Official and Tentative Methods of Analysis, $3 \mathrm{rd} \mathrm{ed.}$

Washington, D.C.: Association of Official Agricultural Chemists.

Bailey, K. (1937). Biochem. 7. 31, 1396.

Borchers, R., Ackerson, C. W. \& Kimmett, L. (1947). Arch. Biochem. 13, 29 I.

Borchers, R., Ackerson, C. W., Sandstedt, R. H. \& Kimmett, L. (1947). Arch. Biochem. 12, 367.

Cama, H. R. \& Morton, R. A. (1950). Brit. F. Nutrit. 4, 297.

Evans, R. J. \& St John, J. L. (1945). F. Nutrit. 30, 209.

Fontaine, T. D. \& Burnett, R. S. (1944). Industr. Engng Chem. (Industr. ed.), 36, 164.

Fontaine, T. D., Samuels, C. \& Irving, G. W. Jr. (1944). Industr. Engng Chem. (Industr. ed.), 36, 625.

Grau, C. R. (1946). Y. Nutrit. 32, 303.

Jones, D. B. (1931). Circ. U.S. Dep. Agric. no. 183.

Lund, A. P. \& Sandstrom, W. M. (1943). F. agric. Res. 66, 349. 